\title{
Perfil socioeconômico de jovens metalúrgicos
}

\author{
Iram Jácome Rodrigues e Heloisa Helena T. de Souza Martins
}

Introdução

De acordo com o Relatório Mundial sobre a Juventude de 2005, elaborado pela ONU, existem hoje, no mundo, 1,2 bilhão de pessoas que estão em situação de risco, ou seja, $18 \%$ da população mundial. Considerando a faixa de idade entre 15 e 24 anos, mais de 200 milhôes vivem com menos de um dólar por dia e 88 milhões não têm emprego (cf. Rodrigues, 2005b, p. A20). Dados como esses têm sustentado argumentos que enfatizam a vulnerabilidade dessa fase da vida, em que os jovens estão expostos aos perigos representados pelo crime, pelas drogas, pela exclusão. Torna-se cada vez mais comum o uso de um referencial teórico que, na análise da sociedade contemporânea, a concebe como uma "sociedade do risco", na qual a dificuldade de elaborar projetos para o futuro atingiria especialmente os jovens. Para estes, a única certeza talvez seja a da imprevisibilidade na construção de uma trajetória em direção à idade adulta ${ }^{1}$. Assim, as trajetórias de vida dos jovens são sempre associadas à falta de linearidade, de normalidade e, principalmente, de homogeneidade.

Com o objetivo de estabelecer um contraponto a essas análises, tomamos como referência um grupo de jovens que, aparentemente, apresentam trajetórias socialmente normalizadas e lineares. Neste artigo, apresentaremos os dados de pesquisa ${ }^{2}$ realizada com trabalhadores da indústria auto-
1. Neste sentido, consultar o texto de Carmem Leccardi publicado neste número de Tempo Social.

2. A pesquisa, elaborada por Iram Jácome Rodrigues, consistiu na aplicação de questionários aos trabalhadores das seguintes montadoras: Volkswagen, MercedesBenz, Ford e Scania, no município de São Bernardo do Campo. Ao todo, foram 432 questionários respondidos pelos trabalhadores, a partir de uma amostra estatística elaborada para as quatro empresas. 
3. De uma maneira geral, os estudos sobre juventude, no Brasil, tomam como referência o intervalo de 15 a 24 anos. Entretanto, especialmente em textos europeus, tem sido comum o prolongamento do limite superior desse intervalo, chegando a superar até mesmo os 30 anos, como, por exemplo, em Pais (2001).

4. Consideramos, neste artigo, que os 71 jovens de nossa amostra constituem uma "unidade geracional", no sentido dado por Mannheim (1982, p. 89), de que é possível perceber "certa afinidade no modo pelo qual todos se relacionam com suas experiências comuns e são formados por elas". Entretanto, isso não nos impede de perceber a diversidade existente entre as "juventudes".

5. Em 1990, eram doze fabricantes de veículos que contavam com dezessete fábricas, em seis municípios do Brasil. No ano de 2002, existiam dezoito fabricantes e 27 fábricas, instaladas em dezoito municípios (cf. Do holerite às compras, Subseção DieeseABC, junho 2003). mobilística na região do $\mathrm{ABC}$, com destaque para os incluídos na faixa etária de 19 a 29 anos $^{3}$. Ainda que a pesquisa não tivesse como preocupação central a questão do jovem trabalhador, foi possível desagregar 71 empregados da amostra de trabalhadores do chão de fábrica que se encontravam naquele intervalo de idade. É sobre esse conjunto de operários que este estudo se debruça, realizando uma análise comparativa entre o perfil socioeconômico desses jovens metalúrgicos e o de seus colegas de trabalho com 30 anos de idade ou mais, que representam uma amostra de 358 funcionários, já que três dos respondentes omitiram a idade.

Este estudo também dialoga com outros autores que realizaram pesquisas com jovens trabalhadores em indústrias do setor metalúrgico (cf. Corrochano, 2001; Souza Martins, 2001, 2004; Tomizaki, 2005), no sentido de mostrar que, embora trabalhando com jovens inseridos no mesmo setor industrial, existem diferenças significativas entre eles quanto às condições de vida e de trabalho que os cercam. Nesse sentido, o destaque será dado à heterogeneidade que caracteriza a juventudé .

As transformações do perfil socioeconômico dos trabalhadores metalúrgicos das montadoras do $\mathrm{ABC}$, ocorridas nas últimas décadas e discutidas em pesquisas recentes (cf. Rodrigues, 2002), tornam-se mais explícitas quando se comparam os mais velhos com os mais jovens quanto às condições de vida e a suas opiniões sobre o local de trabalho. Essa comparação é relevante porque a maioria dos jovens ingressou no mercado de trabalho quando as transformações já estavam em curso, isto é, no final da década de 1990 e início desta. Isso significa que esses jovens não participaram do período mais importante (os anos de 1980 e grande parte da década seguinte) da luta pela melhoria das condições de trabalho e, portanto, não vivenciaram as principais transformaçōes desse processo.

Nos últimos quinze anos (1988-2002) - à exceção dos anos de 1990 e 1991 -, ocorreu um crescimento continuado no conjunto do setor automotivo brasileiro no que tange à produção de veículos. O número de unidades fabricadas por ano passou, de pouco mais de 1 milhão em 1988, para cerca de 1,8 milhão em 2002, ou seja, um aumento da ordem de 80\%. Ao mesmo tempo, em 1988 havia 113 mil postos de trabalho e, quinze anos depois, esse número caiu para 82 mil. Vale dizer, mesmo com o aumento de uma dezena de novas fábricas de veículos na década de 1990, houve um decréscimo de 31 mil trabalhadores nas montadoras do país nesse período5. Isto é, nesse espaço de tempo, foram perdidos aproximadamente um quarto dos postos de trabalho nas empresas 
automotivas. Já em 2004 a indústria automobilística bateu um recorde histórico no país, com uma produção total de 2.205 .873 veículos, o que representou um resultado quase $21 \%$ acima do ano anterior, 1.827 .038 unidades ${ }^{6}$.

Esses números são ainda mais dramáticos para o $\mathrm{ABC}$, quando sabemos que o grande corte dos postos de trabalho ocorreu nas empresas já instaladas no país. Isso porque as novas montadoras estão organizadas nos marcos dos novos modelos de produção e organização do trabalho, o que lhes possibilita uma produtividade bastante elevada com um número extremamente reduzido de empregados e permite, nas fábricas novas, alcançar índices compatíveis com os padrões internacionais. De todo modo, quando juntamos as montadoras antigas e recentes no país, no período analisado, ocorre um salto de produtividade: de nove veículos por trabalhador/ano para 22 veículos por trabalhador/ano. Um crescimento sem precedentes na indústria automobilística brasileira.

Em larga medida, o processo de reestruturação industrial foi o responsável pela diminuição abrupta do número de empregados nas montadoras e empresas de autopeças no $\mathrm{ABC}$ já a partir do final dos anos de 1980, tendência que se acentuou durante a década seguinte. Pela queda da participação da região na produção total de veículos no país, assim como no total de postos de trabalho nesse setor, isso significou um aumento expressivo do desemprego regional e o deslocamento territorial da cidade dos automóveis da outrora "República de São Bernardo" para múltiplos espaços pelo Brasil afora. Foram esses acontecimentos - acrescido da chamada guerra fiscal entre várias unidades da federação - que levaram os metalúrgicos do $\mathrm{ABC}$ a fazer uma reflexão sobre suas práticas cotidianas, suas demandas, suas necessidades, e a proporem novas formas de atuação na tentativa de (re)construção das relações de trabalho, em novas bases, especialmente no espaço da indústria automotiva. Essa inflexão ocorreu nos anos de 1990. Foi a mudança do confronto para a negociação, do discurso de fora para dentro da empresa e de uma ação que privilegiava a negociação a partir da empresa e, ao mesmo tempo, uma política sindical voltada à organização dos trabalhadores no interior das unidades de produção, em particular das montadoras. Foi esse o período que inaugurou a busca do consenso e do entendimento nas relações capital/trabalho, além do desenvolvimento de um conhecimento técnico, extremamente atualizado, sobre a gestão e a organização do trabalho, da produção e dos modelos de produção, entre outros (cf. Rodri-
6. Cf. Carta da Anfavea, São Paulo, jan. 2005. 
gues, 2005a). Diante do exposto, três questôes dirigiram a análise a respeito dos jovens metalúrgicos: Quem é o jovem que trabalha hoje nas montadoras? Esses jovens trabalhadores possuem o mesmo perfil socioeconômico de seus companheiros mais velhos e com mais tempo de casa? As representações que esses jovens trabalhadores possuem de seu local de trabalho se equiparam às de seus colegas mais velhos?

\section{Os atores em cena e a região do $A B C$}

O ABC paulista, em particular o município de São Bernardo do Campo, possui algumas peculiaridades que o tornam ímpar. Ao mesmo tempo em que há um amplo desenvolvimento industrial e, por essa razão, existe uma grande concentração de trabalhadores na região, ocorre também um tipo de ação sindical que se diferencia, em muito, das práticas mais comuns em nosso país. Um dos principais pontos da prática que se desenvolveu no ABC paulista, desde os anos de 1970, se relaciona, de um lado, com a capacidade sindical de dar respostas aos problemas que surgem no cotidiano da produção e, de outro, com sua organização no interior das empresas. Com uma ação amplamente amparada nos temas que surgem no cotidiano da produção, esse sindicalismo deu voz às demandas do operariado em seus locais de trabalho. Em uma região de alta concentração industrial, onde a grande maioria dos operários trabalhava na indústria automotiva do município, cerca de $60 \%$ da mão-de-obra estava concentrada nas montadoras ali instaladas, o que foi um fator decisivo para a nova forma de atuação trabalhista que estava sendo construída no $\mathrm{ABC}$ paulista na década de 1970 e fundamental para os desdobramentos dessa nova prática sindical (cf. Rodrigues, 1997, p. 66).

No caso da experiência brasileira, o final dos anos de 1970 foi crucial para os novos atores sociais, entre os quais podemos destacar o Sindicato dos Metalúrgicos de São Bernardo do Campo e Diadema - posteriormente renomeado como Sindicato dos Metalúrgicos do $\mathrm{ABC}$-, pois naquele momento essa instituição se notabilizou na esfera pública ao defender a liberdade e a autonomia sindical, a organização dos empregados nos locais de trabalho, o fim do controle do Ministério do Trabalho sobre os sindicatos, o direito de greve e a negociação direta entre patrōes e empregados, sem a ingerência do Estado, entre outros aspectos.

Analisando a trajetória do sindicalismo no ABC, Comin, Cardoso e Campos (1997, p. 422) argumentam que ele 
[...] literalmente protagonizou a cena sindical brasileira nos últimos 20 anos, promovendo enormes movimentos grevistas, mas também algumas das experiências mais inovadoras de negociação coletiva e pactação setorial; rompeu com alguns aspectos da estrutura sindical oficial ao iniciar a devolução do imposto sindical aos trabalhadores e ao recusar os recursos à Justiça do Trabalho para a realização de acordos coletivos; encabeçou o movimento de unificação sindical através da fundação da CUT; encabeçou a unificação da negociação coletiva dos sindicatos dos metalúrgicos filiados à CUT, consubstanciada na Federação dos Metalúrgicos dessa central; ostenta um índice de sindicalização (hoje em torno de $60 \%$ na categoria como um todo e chegando a $90 \%$ nas montadoras de automóveis) muito superior ao da média nacional, exibindo forte penetração, através de comissões de fábrica, nas grandes empresas da região. Não resta dúvidas de que esse sindicalismo logrou enraizar-se na sua base num país onde esse enraizamento é, formalmente, desnecessário como lastro e representação sindical.

O conjunto dessas ações resultou, de maneira paulatina, em uma nova forma de atuação no campo das relações trabalhistas, que posteriormente ficou conhecida como novo sindicalismo ${ }^{7}$. A passagem de uma luta extremamente defensiva e localizada para uma ação mais ampla, no final dos anos de 1970 e início da década seguinte, quando os conflitos começaram a eclodir por todo o território nacional, com grandes greves por categorias, por fábricas, e mesmo greves gerais, significou uma mudança na ação sindical no Brasil ${ }^{8}$. O momento mais representativo dessa nova atuação se expressou nas paralisações por fábrica, que, iniciando-se em São Bernardo, em maio de 1978, estenderam-se, em seguida, por praticamente todo o Brasil (cf. Rodrigues, 1997).

O Grande $\mathrm{ABC}^{9}$ é uma das regiōes mais ricas do país. Sua renda per capita, medida em dólar, era de 13.054 em 2000. Apenas para efeito de comparação, a renda per capita brasileira é de 3.620 dólares, ao passo que no estado de São Paulo ela é de aproximadamente 6 mil dólares e na região

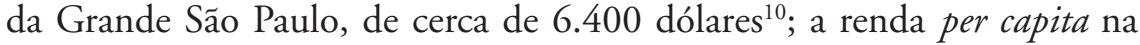
região do $\mathrm{ABC}$ é maior que a da Espanha (12.209) e um pouco inferior à do Reino Unido (14.170). Além disso, o Produto Interno Bruto dos municípios que compõem o Grande $\mathrm{ABC}$ é superior ao PIB individual de dezenove estados da federação ${ }^{11}$.

No tocante aos dados sobre emprego na região, os municípios que possuíam o maior número de postos de trabalho em 1999 eram São Bernardo do Campo, com 38,1\% do total; Santo André, 23,8\% ; Diadema, 15,1\% e
7. Muitos autores dedicaram-se ao estudo desse movimento e de seus desdobramentos. Cf., por exemplo, Almeida (1975); Maroni (1982); Rainho e Bargas (1983); Sader (1988); Martins Rodrigues (1990b); Boito Júnior (1991); Antunes (1988, 1991); Mangabeira (1993); Souza Martins (1994); Galvão (1996); Soares (1998); Blass (2001); Véras de Oliveira (2002); Paranhos (1999, 2002). Para uma crítica da noção de "novo sindicalismo", ver Santana (1999).

8. Para uma discussão sobre sindicalismo e relaçôes de trabalho no período inaugurado com as greves de 1978 até o segundo mandato de FHC, ver Oliveira (2002, pp. 221-340).

9. O grande $\mathrm{ABC}$ é formado pelos municípios de Santo André, São Bernardo, São Caetano, Diadema, Mauá, Ribeirão Pires e Rio Grande da Serra.

10. Segundo a Revista ABC Brazil, (2): 6, fev.l mar. 2000.

11. Revista ABC Brazil, (2): 6, fev./mar. 2000. 
São Caetano do Sul, com 13,8\% (cf. Grande $A B C$ em números, p. 102). Vale dizer, do conjunto dos sete municípios que fazem parte da região, os postos de trabalho em São Bernardo equivaliam a aproximadamente $40 \%$ e as quatro cidades acima detinham, juntas, 90,8\% dos empregos.

Ainda no que tange ao emprego, chama a atenção o fato de que, no período que vai de 1989 a 1999, o emprego na indústria caiu de 52\% dos postos de trabalho para apenas $30 \%$; já o emprego no comércio, no mesmo intervalo de tempo, subiu de $12 \%$ para $22 \%$, ao passo que os serviços foram de $36 \%$ para $48 \%$ (cf. Idem, p. 94). Nesses onze anos, ocorreu um crescimento significativo do emprego no setor terciário, passando de $48 \%$ para $70 \%$, e uma queda acentuada do emprego industrial. Em parte, esse processo de perda de postos de trabalho no setor industrial na região pode ser percebido quando se compara a participação relativa da produção de veículos no total nacional entre 1975 e 1998. Naquele ano, a produção regional foi de 803.785 veículos, o que equivalia a $86,4 \%$ da produção nacional, que chegou a 930.235 veículos. No entanto, em 1999, a região produziu apenas 535.741 autoveículos, contra 1.585.630 fabricados no país, isto é, a participação do $\mathrm{ABC}$ na produção nacional caiu para 33,8\% (cf. Conceição, 2001, p. 64).

A queda na participação da produção de veículos e do emprego industrial na região ganha mais relevância quando se considera que, em 1999, o complexo da produção automotiva significava aproximadamente $40 \%$ do valor adicionado e $27 \%$ da mão-de-obra ocupada na indústria do Grande ABC (cf. Idem, p. 10).

Alguns fatores favoreceram a diminuição, tanto relativa como absoluta, do trabalho industrial no $\mathrm{ABC}$. Em primeiro lugar, é um processo que acompanha uma tendência internacional - decorrência da chamada globalização -, presente principalmente nos países centrais; em segundo lugar, é resultado da ampla reorganização produtiva nas últimas duas décadas, da guerra fiscal e das mudanças na política macroeconômica do último decênio. $\mathrm{O}$ caso da indústria de autopeças na região é, nesse aspecto, exemplar:

Ao longo da década [de 1990] a indústria de autopeças foi praticamente reconstruída, de acordo com a nova estratégia de compras de peças liderada pelas montadoras. Esta estratégia envolveu contratos de fornecimento global e não mais apenas nacional ou local; a hierarquização dos fornecedores em níveis; a instalação de unidades de fornecedores geograficamente próximas das montadoras; o suprimento das linhas de montagem de veículos em forma de módulos de componentes 
completos e a redução do número de empresas fornecedoras (cada montadora reduziu o número de seus fornecedores diretos, de milhares para algumas centenas). Estas medidas foram facilitadas pelas políticas de liberalização de importações com destaque para o Regime Automotivo - e pela guerra fiscal, na segunda metade da década (Conceição, 2001, pp. 193-194).

Dessa forma, no último decênio, as mudanças que já vinham se desenvolvendo de maneira paulatina na região explodiram de vez: a vocação do $A B C$ se transformou. De um pólo eminentemente industrial e berço da produção automotiva, passou a ser um espaço regional de alta concentração do setor de serviços, como sói ocorrer, de resto, em regióes, estados e/ou municípios mais desenvolvidos, em muitas partes do mundo.

Segundo Klink (2001, p. 199), "na década de 1990 o Grande ABC atravessou um momento difícil, com queda de postos de trabalho nos setores-chave, como o setor metalúrgico, químico, metal-mecânico e automobilístico, que é mais acentuada do que a redução de emprego nesses setores no estado de São Paulo como um todo". No entanto, para esse autor,

[...] muito mais que o reflexo de uma transformação mais estrutural do tipo daquela que ocorreu em economias regionais estrangeiras, os ganhos que a região obteve em determinados setores de terciário, como, por exemplo, os serviços técnicos e profissionais e o comércio varejista, relacionam-se com o caráter tardio de desenvolvimento desses setores no Grande $\mathrm{ABC}$ em relação à região metropolitana. Mesmo assim, a relativa participação de setores como os de serviços técnicos e profissionais no conjunto do emprego do Grande ABC está ainda longe dos patamares da Capital, cuja pujança nesses setores permanece incontestável (Idem, ibidem).

São essas as condições que hoje norteiam o trabalho e a vida dos metalúrgicos que fizeram parte da pesquisa. Sem levá-las em consideração, fica difícil entender as atitudes e as orientações desses trabalhadores, especialmente dos jovens que, nascidos entre os anos de 1973 e 1982, tiveram sua trajetória pessoal e profissional marcada por esses acontecimentos.

\section{A pesquisa}

Uma das questôes que orientaram a pesquisa, e que é também central neste artigo, diz respeito à possibilidade de apreensão das atitudes e das opiniões de um grupo de operários que trabalham em empresas multina- 
cionais do ramo automobilístico. Como observa Martins Rodrigues (1970, p. XII),

[...] as atitudes dos operários ante o trabalho fabril e a sociedade industrial não são as mesmas em todas as épocas e em todos os países. Embora seja possível encontrar certos componentes "universais" do comportamento operário, que decorrem da posição que a classe ocupa no sistema de produção e na sociedade inclusiva (defesa de seus interesses profissionais e econômicos, de sua autonomia organizatória etc.), as formas de organização sindical e política, assim como as ideologias, têm variado segundo as características do processo de industrialização, do modo particular de formação da classe, do sistema político imperante etc.

Nesse caso, analisando o grupo estudado, vamos observar percepções diferenciadas daquelas que foram encontradas por Martins Rodrigues (1970, 1990a) ou Rodrigues (1990). Se tomarmos como exemplo o ambiente externo às empresas, vamos observar transformaçóes que há vinte ou trinta anos não poderíamos imaginar, tanto no plano nacional como internacional. De outra parte, o interior da firma, palco de tantos conflitos no último século e locus, por excelência, da relação capital/trabalho, também passou por profundas alteraçōes. Esses fatores sem dúvida influenciaram fortemente a percepção dos trabalhadores sobre uma vasta gama de questôes. Somem-se a isso as mudanças no interior das próprias classes trabalhadoras. No setor em questão, a predominância é de empregados de origem urbana, segunda geração industrial, nascidos na capital do estado ou na Grande São Paulo, com um alto grau de instrução em termos comparativos, com mais idade e mais tempo na companhia e, por isso mesmo, mais qualificados e com maior experiência de trabalho na indústria. Além disso, mais sindicalizados e com tradição de participação política.

Os trabalhadores do segmento automotivo, em especial aqueles que estão alocados nas quatro principais montadoras no município de São Bernardo do Campo, possuem um diferencial significativo quando comparados com outros empregados de ramos distintos do setor industrial brasileiro: têm salários bem mais altos que a média nacional, mesmo se comparados com os que vigem em outras empresas automotivas do país, têm muito tempo de trabalho na companhia e uma situação de emprego bastante estável para os padrões nacionais. Além disso, nesse caso específico, esses trabalhadores possuem uma capacidade de pressão política muito grande, significativa participação sindical construída em todos es- 
ses anos e, em alguma medida, dadas as peculiaridades do sindicato dos metalúrgicos do $\mathrm{ABC}$, têm conseguido manter uma forte identidade política como classe trabalhadora (cf. Rodrigues, 2002). Para usarmos o termo cunhado por Waterman (1999), expressariam com sua prática um novo sindicalismo social.

Antonio Candido, em seu livro Os parceiros do Rio Bonito, chama a atenção para o seguinte aspecto:

[...] não hesitei pois em situar o grupo estudado, tanto na perspectiva histórica, quanto no complexo de problemas que hoje caracterizam a vida rural de São Paulo. Como o leitor verá, quando falo nos membros do grupo que estudei, estou a cada momento pensando no caipira, em geral; e, reciprocamente, quando procuro compor esta abstração metodologicamente útil, a experiência real que a comprova é, sobretudo, a do grupo que estudei (Candido, 1964, p. 6).

Parafraseando Antonio Candido, poderíamos dizer que quando discorremos sobre o grupo de trabalhadores pesquisado estamos, "a cada momento, pensando" no empregado da grande empresa como tal e, à medida que discutimos sobre a trajetória das classes trabalhadoras e do sindicalismo brasileiros, o que nos dá a concretude real de sua experiência é, principalmente, o grupo estudado.

Assim, a abordagem metodológica utilizada neste estudo procura desenvolver, da mesma forma, portanto, algumas questôes relativas ao conjunto dos trabalhadores da indústria automobilística, a partir do estudo de um grupo de empregados do chão de fábrica de quatro grandes empresas do setor automotivo. À parte o contingente de mão-de-obra empregado nessas fábricas, é importante ressaltar a grande experiência de luta e organização desses trabalhadores. Desse modo, é um estudo que, em suas características mais gerais, pode representar uma tendência indicativa - guardadas as proporçôes - do que se passa com amplos setores das classes trabalhadoras em nosso país, em particular no segmento automotivo e, mais especificamente, com jovens trabalhadores. A mesma abordagem metodológica poderia ser pensada para a reflexão sobre a ação sindical desse grupo.

Os trabalhadores que compuseram a amostra foram selecionados de um total de 30.866 operários - número de empregados nas montadoras na base do sindicato dos metalúrgicos do $\mathrm{ABC}$-, dos quais 23.399 são sindicalizados (dez. 2002). O grupo estudado representa a espinha dorsal do 
12. Esse questionário foi uma adaptação, para as quatro montadoras em tela, do questionário confeccionado pelos colegas José Ricardo Ramalho e Marco Aurélio Santana e utilizado com os trabalhadores da fábrica da Volskswagen de Resende, como parte de pesquisa comparativa entre o sul fluminense e o ABC paulista, que estamos realizando e que conta com o apoio do CNPq.

13. Para a definição da amostra foi fundamental o apoio do colega Heron do Carmo, do Departamento de Economia da USP, especialista nessa questão, a quem agradecemos. sindicalismo no ABC e foi a base, desde os anos de 1970-1980, das transformaçôes pelas quais passou o sindicalismo tanto na região como nacionalmente. Assim como, naquela época, foram o ponto de apoio para o movimento que se convencionou chamar de novo sindicalismo, hoje, com suas atitudes, orientações e práticas estão escrevendo, quiçá, um novo capítulo da história do sindicalismo no Brasil.

A pesquisa foi realizada nas quatro montadoras entre março e junho de 2003. Em média, levou-se um mês para a aplicação em cada empresa. Como nas quatro firmas a densidade de sindicalização é muito alta, $76 \%$ em média - e, no caso da Volkswagen, esse percentual atinge $85 \%$ dos funcionários -, optou-se por fazer a aplicação dos questionários apenas entre os empregados sindicalizados das quatro empresas ${ }^{12}$. A listagem dos funcionários sindicalizados foi obtida no sindicato e, a partir disso, tendo-se chegado ao número representativo da amostra para cada empresa, foi realizado um sorteio aleatório dos trabalhadores que responderiam ao questionário ${ }^{13}$.

\section{A juventude metalúrgica}

Um dos aspectos que chama a nossa atenção na amostra da pesquisa realizada nas montadoras é a pouca presença de jovens: apenas 71 , ou seja, $16,4 \%$ do total de trabalhadores da amostra. Contudo, outros autores também têm evidenciado a presença, em maior proporção, de trabalhadores com mais idade nas montadoras do estado de São Paulo. Em 1999, segundo Tomizaki (2005, p. 146), 75,6\% dos trabalhadores do chão de fábrica das montadoras possuíam mais de 30 anos. Na Mercedes-Benz, em 2002, a idade média dos trabalhadores era de 38,2 anos e os que estavam na faixa dos 15 aos 30 anos eram 2.018 em um total de 9.327 empregados, o que representa 21,6\%. Em pesquisa realizada em três empresas metalúrgicas com número diferente de trabalhadores, Corrochano (2001) verificou que a presença de jovens era maior na que tinha 92 funcionários (22\%), do que nas de tamanho médio (20\%) e grande (11\%). O que esses estudos e outros (cf. Souza Martins, 2001, 2004) têm revelado é que os jovens operários iniciam sua trajetória profissional geralmente em pequenas indústrias, nas quais, muitas vezes, adquirem os conhecimentos e a experiência que os tornam "empregáveis" em empresas maiores. Trabalhar em uma montadora, portanto, parece constituir o ápice de uma carreira que, especialmente no caso dos jovens do sexo masculino, começa muito cedo. 
No que tange ao grupo estudado, é importante ressaltar alguns aspectos: são jovens trabalhadores empregados nas montadoras do $\mathrm{ABC}$ paulista, região que, como foi assinalado anteriormente, possui um amplo parque industrial automotivo - o mais antigo do país - e um sindicato que tem desempenhado um relevante papel na organização dos trabalhadores no âmbito local, regional e mesmo nacional nos últimos 25 anos. Além disso, é um grupo com forte tradição operária, geralmente filhos de metalúrgicos e, nesse aspecto, a segunda ou até mesmo a terceira geração de trabalhadores industriais. E, dado muito significativo, $45 \%$ deles estavam no seu primeiro emprego, enquanto $28 \%$ já tinham experiência de trabalho na indústria. À primeira vista, quando comparados com jovens trabalhadores metalúrgicos de outras empresas que não as montadoras ou com jovens trabalhadores em geral, poderíamos ser tentados a dizer que são privilegiados. De fato, possuem maior nível de escolaridade e formação profissional, e emprego estável, com carteira assinada. Além disso, se considerarmos que na região metropolitana de São Paulo a taxa de desemprego para os jovens de 18 a 24 anos chega a quase $27 \%$, enquanto no total da população é de $17,5 \%{ }^{14}$, somos levados a afirmar que eles constituem um grupo diferenciado, ao abrigo das mazelas que atingem os trabalhadores brasileiros. No entanto, a despeito, por exemplo, dos salários mais altos e das melhores condições de trabalho, quando comparado com o restante da juventude trabalhadora, nota-se também no interior desse grupo as mesmas inseguranças com relação ao trabalho que estão presentes naqueles; o fato de terem melhores condições em termos salariais e/ou de emprego não os afasta muito dos problemas que são comuns à juventude.

A comparação com os dados das pesquisas realizadas com jovens metalúrgicos por Corrochano e Souza Martins mostra que existe uma maior semelhança entre eles do que com os jovens entrevistados por Tomizaki e, obviamente, com os jovens da nossa pesquisa. Os dois primeiros estudos foram realizados respectivamente no $\mathrm{ABC}$ e em Osasco, com jovens de 18 a 24 anos que trabalhavam em indústrias pequenas, médias e grandes (mas nenhuma com mais de 1.200 empregados na produção), nas quais não houve mudanças significativas no modo de trabalhar nem mesmo no que se refere à introdução de inovaçôes técnicas. Os jovens, em sua maioria não-qualificados ou semiqualificados, aprenderam a executar suas tarefas no próprio trabalho e são oriundos de famílias com pouca ou nenhuma tradição operária, que vêem no trabalho na indústria metalúrgica a possibilidade de aprender uma profissão. Tomizaki, por sua vez, entrevistou
14. Segundo dados referentes ao mês de julho de 2005, da Pesquisa de Emprego e Desemprego-PED, realizada pelo Dieese/Fundação Seade.

novembro 2005 
jovens de 20 a 34 anos, operários de uma montadora, em sua grande maioria nascidos em municípios da Grande São Paulo, filhos de metalúrgicos e na quase totalidade solteiros.

Poderíamos também comparar os metalúrgicos que hoje trabalham nas montadoras do $\mathrm{ABC}$ com os da primeira geração de trabalhadores dessas empresas: eram majoritariamente migrantes vindos de outras partes do país, notadamente do Nordeste, com baixa escolaridade, sem tradição de trabalho na indústria, sem formação profissional, exercendo funções não-qualificadas ou semiqualificadas. Mas, apesar de tudo o que enfrentaram, podese dizer que são trabalhadores vitoriosos, pois ao assumir um lugar nas montadoras atingiram "um posicionamento social 'privilegiado', em termos de renda, tipo de ocupação, posição no mercado de trabalho, escolaridade e qualificação" (Tomizaki, 2005, p. 58).

Enfim, quem são esses jovens trabalhadores, herdeiros dessa tradição? Conforme as Tabelas 1, 2 e 3, são predominantemente do sexo masculino (96\%); se auto-identificam como brancos (79\%), negros (7\%) e pardos (14\%); na sua maioria são católicos (66\%) e 13\%, um percentual expressivo, se declararam sem religião. Entretanto, esses dados não diferem substancialmente dos resultados da pesquisa "Perfil da juventude brasileira", na qual $11 \%$ dos jovens se declararam sem religião (cf. Novaes, 2005, p. 266). Essa mesma autora alerta para o empobrecimento das análises que apressadamente afirmam a indiferença dos jovens diante da religião. O mais significativo, a nosso ver, é que, quando se analisa a inserção dos jovens em grupos, o que se observa em primeiro lugar é a participação em "grupos da Igreja" (Novaes, 2005, p. 264). Em nossa pesquisa, apenas um terço dos jovens disseram que participavam em atividades na comunidade, mas, destes, 65\% afirmaram que essas atividades eram relacionadas com a religião.

\begin{tabular}{|c|c|c|c|}
\hline & FAIXA ETÁRIA & 30 anos ou mais (\%) & Até 29 anos (\%) \\
\hline \multicolumn{4}{|l|}{ SEXO } \\
\hline Masculino & & 95 & 96 \\
\hline Feminino & & 5 & 4 \\
\hline TOTAL & & 100 & 100 \\
\hline
\end{tabular}




\begin{tabular}{lcc}
$\begin{array}{l}\text { TABELA } 2 \\
\text { Raça }\end{array}$ & FAIXA ETÁria & Até 29 anos (\%) \\
\hline RAÇA & 69 & 79 \\
\hline Branca & 6 & 7 \\
Negra & 23 & 14 \\
Parda & 1 & 0 \\
Amarela & 1 & 0 \\
Indígena & 100 & 100 \\
\hline TotAL & &
\end{tabular}

TABELA 3

Religião

\begin{tabular}{lcc}
\hline & FaIXA ETÁria & Até 29 anos ou mais (\%) \\
Religiāo & 70 & 66 \\
\hline Católica & 4 & 4 \\
Batista & 3 & 9 \\
Assembléia de Deus & 2 & 1 \\
Universal & 3 & 1 \\
Espírita & 4 & 13 \\
Sem religião & 0 & 1 \\
Ateu & 14 & 5 \\
Outras & 100 & 100 \\
\hline Total & &
\end{tabular}

Como sublinhado anteriormente, optamos por mostrar nas tabelas, para as mesmas questões, a contraposição entre o grupo etário de 19 a 29 anos e o de mais de 30 anos. Isso, certamente, nos ajuda a compor um panorama mais próximo da realidade e, ao mesmo tempo, explicita as semelhanças e as diferenças entre as faixas etárias.

No tocante ao estado ou região de origem, é interessante observar que 91\% nasceram no estado de São Paulo, sendo que, desses, apenas 3\% são originários do interior, como mostram as Tabelas ${ }^{15} 4$ e 5 . Vale dizer, é uma jovem classe operária de origem nitidamente urbana. Quando comparados com o grupo mais velho de empregados, esses dados tornam-se ainda mais 15. Agradecemos a Cecilia Pontes pela confecção das tabelas. expressivos: neste caso, apenas 59\% nasceram no estado de São Paulo. 
TABELA 4

Estado ou região de origem

\begin{tabular}{|c|c|c|c|}
\hline $\begin{array}{l}\text { ESTADO } \\
\text { OU REGIĀO DE ORIGEM }\end{array}$ & FAIXA ETÁRIA & 30 anos ou mais (\%) & Até 29 anos (\%) \\
\hline São Paulo & & 59 & 91 \\
\hline Sudeste (exceto São Paulo) & & 9 & 0 \\
\hline Nordeste & & 23 & 4 \\
\hline Centro-Oeste & & 1 & 0 \\
\hline Sul & & 8 & 5 \\
\hline TOTAL & & 100 & 100 \\
\hline
\end{tabular}

TABELA 5

Nascidos no estado de São Paulo

\begin{tabular}{|c|c|c|c|}
\hline NASCIDOS EM & FAIXA ETÁRIA & 30 anos ou mais (\%) & Até 29 anos (\%) \\
\hline Capital & & 27 & 25 \\
\hline Interior & & 21 & 3 \\
\hline Santo André (SP) & & 23 & 36 \\
\hline São Bernardo (SP) & & 12 & 21 \\
\hline São Caetano (SP) & & 10 & 9 \\
\hline Grande SP (exceto SP e ABC) & & 7 & 6 \\
\hline TOTAL & & 100 & 100 \\
\hline
\end{tabular}

Chama a atenção, por outro lado, o percentual de jovens trabalhadores que nasceram na região do $\mathrm{ABC}(66 \%)$. Já no grupo com faixa etária mais elevada, esse total é de apenas $43 \%$. O significado desses dados é realçado quando vemos que, na pesquisa realizada por Corrochano, $48,6 \%$ dos jovens nasceram em outros estados, vindos em grande parte da zona rural, enquanto apenas 36,1\% tinham nascido no Grande ABC. E, mais ainda, são jovens filhos de migrantes, que deixaram seus lugares de origem sozinhos ou acompanhando a família, entre os anos de 1993 e 1998.

Com relação à situação conjugal, ainda que a maioria seja de solteiros, o percentual de casados ou vivendo maritalmente aproxima-se de $40 \%$ entre os mais jovens e de quase $90 \%$ entre os mais velhos, como mostra a Tabela 6.

234 Tempo Social, revista de sociologia da USP, v. 17, n. 2 
TABELA 6

Situação conjugal

\begin{tabular}{|c|c|c|c|}
\hline & FAIXA ETÁRIA & 30 anos ou mais (\%) & Até 29 anos (\%) \\
\hline \multicolumn{4}{|l|}{ SITUAÇĀO CONJUGAL } \\
\hline Solteiro & & 6 & 59 \\
\hline Casado ou vivendo maritalmente & & 89 & 39 \\
\hline Divorciado & & 4 & 2 \\
\hline Viúvo & & 1 & 0 \\
\hline TOTAL & & 100 & 100 \\
\hline
\end{tabular}

Além disso, conforme a Tabela 7 , quase $70 \%$ dos jovens não têm filhos e o restante deles têm de um a dois filhos no máximo. Esses dados são, para os maiores de 30 anos, de $23 \%$ e $44 \%$, respectivamente. De qualquer maneira, é interessante observar que apenas $6 \%$ dos funcionários dessas montadoras têm mais de três filhos.

TABELA 7

Número de filhos

FAIXA ETÁria $\quad 30$ anos ou mais (\%) Até 29 anos (\%)

NÚMERO DE FILHOS

\begin{tabular}{lcc}
\hline Sem filhos & 9 & 68 \\
1 filho & 23 & 22 \\
2 filhos & 44 & 10 \\
3 filhos & 18 & 0 \\
Mais de 3 filhos & 6 & 0 \\
\hline TотAL & 100 & 100
\end{tabular}

A questão do nível de escolaridade é tratada nas Tabelas 8, 9, 10 e 11, que mostram quem está ou não estudando, onde os trabalhadores estudam, se fizeram ou não curso profissionalizante e, em caso afirmativo, onde fizeram. Entre os jovens pesquisados, quase $50 \%$ estão estudando, contra apenas $16 \%$ entre os mais velhos. Entre os jovens que estão estudando, mais de $90 \%$ estão em escolas privadas, mas também é alto o percentual de trabalhadores acima de 30 anos que pagam por seus estudos ${ }^{16}$.

16. É preciso considerar que, além da aplicação de parte do tempo reservado ao lazer, esses trabalhadores ainda investem parte de seus salários no pagamento da educação. 
TABELA 8

Empregados que estão estudando

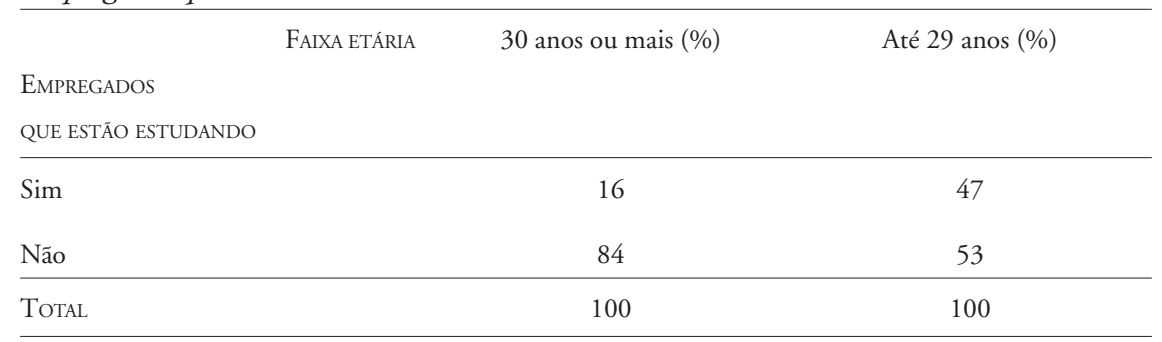

TABELA 9

Rede de ensino em que estuda

\begin{tabular}{|c|c|c|c|}
\hline & FAIXA ETÁRIA & 30 anos ou mais (\%) & Até 29 anos (\%) \\
\hline Pública municipal & & 8 & 3 \\
\hline Pública estadual & & 13 & 6 \\
\hline Particular & & 79 & 91 \\
\hline TOTAL & & 100 & 100 \\
\hline
\end{tabular}

Por outro lado, a esmagadora maioria dos jovens fez curso profissionalizante (82\%); já entre aqueles com mais de 30 anos, esse percentual é de $60 \%$. Entre as instituições que ajudaram na formação profissional, o Senai aparece como a mais importante para os dois grupos estudados (a Tabela 11 permite mais de uma resposta). Vale dizer, o percentual do grupo de faixa etária menor que está estudando é praticamente três vezes maior que o do grupo de trabalhadores mais velhos. Além disso, nesse grupo apenas $18 \%$ não fizeram curso profissionalizante contra mais do dobro do percentual entre os mais velhos (40\%). Conclui-se, portanto, que o grupo de jovens operários tem maior formação profissional e é mais escolarizado, destacando-se quando comparados com o restante de empregados de faixa etária mais elevada.

TABELA 10

Curso profissionalizante

\begin{tabular}{|c|c|c|c|}
\hline & FAIXA ETÁRIA & 30 anos ou mais $(\%)$ & Até 29 anos (\%) \\
\hline \multicolumn{4}{|l|}{ Curso } \\
\hline \multicolumn{4}{|c|}{ PROFISSIONALIZANTE } \\
\hline Sim & & 60 & 82 \\
\hline Não & & 40 & 18 \\
\hline TOTAL & & 100 & 100 \\
\hline
\end{tabular}

236 Tempo Social, revista de sociologia da USP, v. 17, n. 2 
TABELA 11

Onde realizou o curso profissionalizante

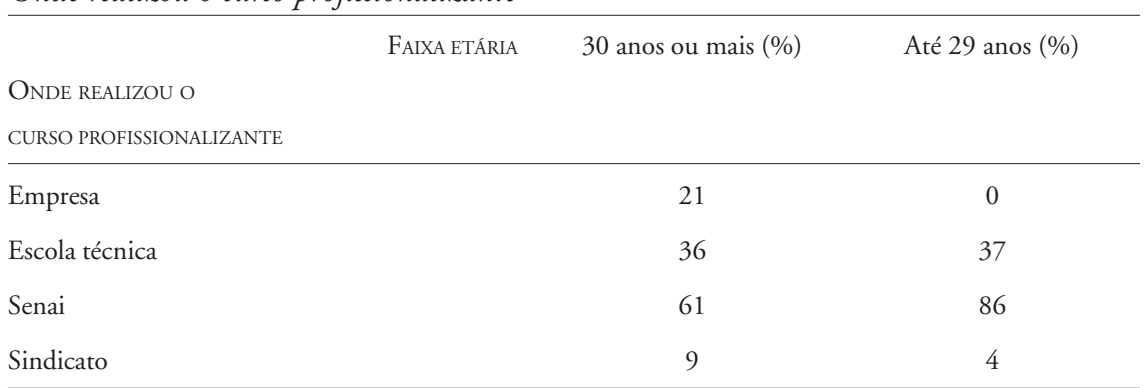

Com relação ao grau de escolaridade, vemos pela Tabela 12 que a maior proporção de trabalhadores das duas faixas etárias tem o ensino médio completo. Entretanto, os jovens apresentam um índice maior de escolaridade, pois $55 \%$ deles têm o curso superior incompleto ou completo ${ }^{17}$. Entre os mais velhos, apenas 13\% atingiram esse nível de ensino. É também entre os que têm acima de 30 anos que encontramos trabalhadores que conseguiram atingir apenas o ensino fundamental (completo e incompleto), enquanto na faixa etária de 19 a 29 anos não há nenhum trabalhador com escolaridade inferior ao ensino médio.

TABELA 12

Escolaridade

FAIXA ETÁria $\quad 30$ anos ou mais (\%) Até 29 anos (\%)

ESCOLARIDADE

\begin{tabular}{lcc}
\hline Ensino fundamental incompleto & 13 & 0 \\
Ensino fundamental completo & 14 & 0 \\
Ensino médio incompleto & 9 & 5 \\
Ensino médio completo & 47 & 40 \\
Superior incompleto & 7 & 33 \\
Superior completo & 6 & 22 \\
Pós-graduação incompleta & 1 & 0 \\
Pós-graduação completa & 3 & 0 \\
\hline TOTAL & 100 & 100 \\
\hline
\end{tabular}

Esses dados revelam uma condição excepcional dos jovens no que se refere à escolaridade. De certa forma, confirmam as informaçōes a respeito da redução das taxas de analfabetismo e do aumento da escolaridade média dos jovens brasileiros de 15 a 24 anos $^{18}$. Diferentes pesquisas demonstram que, diante do mercado de trabalho cada vez mais exigente, os jovens têm prolon-

17. A pesquisa realizada por Corrochano (2001) mostra uma realidade muito diferente; nela, os jovens metalúrgicos apresentam nível de escolaridade mais baixo: $22 \%$ tinham ensino fundamental incompleto, $15 \%$ o fundamental completo, $38 \%$ o ensino médio incompleto, $21 \%$ ensino médio completo e apenas $4 \%$ estavam cursando o ensino superior.

18. Comparando os anos de 1995 e 2001, segundo os dados da PNAD, observa-se um crescimento de $38,5 \%$ para todos os graus de ensino. Os aumentos mais significativos foram nas taxas referentes ao ensino médio $(65,1 \%)$ e ao ensino superior $(88,7 \%)$ (cf. Sposito, 2005, p. 98).

19. Sposito, analisando 
gado sua permanência na escola e os adultos voltam a procurá-la, demonstrando, assim, que a mensagem de que é necessário estudar sempre, a fim de garantir condições que os façam ingressar mais facilmente no mercado de trabalho ou permanecer nele, tem sido assimilada pelos trabalhadores. Estudar, portanto, faz parte de uma estratégia definida pelos jovens e seus pais com vistas ao futuro, afirmando a crença na educação como um instrumento de mobilidade social.

De outra parte, a Tabela 13 mostra a escolaridade paterna do grupo de jovens operários, bem como dos trabalhadores com mais de 30 anos. O que se observa, nos dois casos, é a tendência à maior escolarização dos filhos quando comparados com os pais. Mas existem diferenças significativas entre a escolaridade dos pais para as duas faixas etárias, especialmente nos níveis mais baixos e mais altos do ensino. Enquanto $65 \%$ dos trabalhadores na faixa etária acima de 30 anos tinham pais analfabetos (20\%) ou com alguns anos do curso fundamental (45\%), para os mais jovens a taxa nesses dois níveis de ensino é de pouco mais de 30\%. Quanto ao ensino fundamental completo, as taxas praticamente se igualam. É a partir do ensino médio que as diferenças se acentuam: enquanto somente $8 \%$ dos trabalhadores com mais de 30 anos têm pais com ensino médio completo ou incompleto, 33\% dos jovens têm pais que atingiram esse nível de ensino. E são os pais dos jovens que apresentam uma presença maior no nível superior de ensino, seja completo ou incompleto: $10 \%$, contra apenas $2 \%$ da outra faixa.

TABELA 13

Escolaridade paterna

\begin{tabular}{|c|c|c|c|}
\hline & FAIXA ETÁRIA & 30 anos ou mais (\%) & Até 29 anos (\%) \\
\hline \multicolumn{4}{|l|}{ ESCOLARIDADE PATERNA } \\
\hline Analfabeto & & 20 & 3 \\
\hline Ensino fundamental incompleto & & 45 & 29 \\
\hline Ensino fundamental completo & & 25 & 26 \\
\hline Ensino médio incompleto & & 3 & 9 \\
\hline Ensino médio completo & & 5 & 24 \\
\hline Superior incompleto & & 1 & 6 \\
\hline Superior completo & & 1 & 4 \\
\hline TOTAL & & 100 & 100 \\
\hline
\end{tabular}

A pesquisa não permite avaliar com mais profundidade o significado da educação e da escola para esses trabalhadores. Fica evidente que, tanto para os mais jovens como para os mais velhos, houve uma acentuada progressão 
nos níveis de escolaridade, principalmente quando comparados com os de seus pais. Podemos presumir que isso tem relação com as exigências do mercado de trabalho no contexto da reestruturação produtiva, e especificamente com a necessidade de corresponder às expectativas das montadoras. Se considerarmos as pesquisas com jovens metalúrgicos tomadas aqui como referência, veremos que a relação dos jovens com a escola é marcada por contradições e ambigüidades ${ }^{19}$. Particularmente no estudo de Corrochano (2001), notamos que existe por parte dos jovens o reconhecimento da importância da escolarização, tendo em vista as exigências do mercado de trabalho, o desejo de buscar conhecimentos e, principalmente, a necessidade de fazer amigos, de conviver com outros jovens. Por outro lado, contudo, afirmam que a escola não prepara para o mercado de trabalho, nem garante um lugar nele.

A pesquisa feita por Tomizaki na Daimler-Chrysler (Mercedes-Benz) encontrou jovens mais qualificados, a quase totalidade com cursos técnicos do Senai, a grande maioria com curso superior completo ou incompleto. Mas, tanto para esses jovens como para os da pesquisa de Corrochano, o trabalho na fábrica não corresponde ao que esperam para o futuro. Para os jovens da Mercedes-Benz, a procura pelo curso superior é motivada pelo desejo de escapar da condição operária ou, pelo menos, de ascender profissionalmente na empresa. Essa montadora tem a política de financiar em parte os estudos de seus funcionários, mas já está repensando essa prática, pois se verifica um aumento do nível de insatisfação desses jovens operários universitários que começam a perceber a impossibilidade de "crescer" dentro da empresa ${ }^{20}$.

Para os jovens entrevistados por Corrochano, estudar, além de constituir um meio para escapar do trabalho na fábrica, figura também como uma garantia de permanência em empregos que, mesmo não oferecendo muitas perspectivas de ascensão profissional, garantem a sobrevivência. De uma maneira geral, para uma grande parte dos jovens metalúrgicos abordados nessas pesquisas, incluindo a de Souza Martins (2001, 2004), o trabalho nas fábricas, especialmente aquelas que pagam baixos salários e não oferecem boas condições de trabalho, aparece como provisório, como algo pelo qual devem passar nessa fase da vida, enquanto adquirem habilidades e competências, na escola e no emprego, que lhes permitam ascender profissional e socialmente. Mas o que se pode observar é que, cada vez mais, esse provisório parece se transformar em definitivo e poucos são os que conseguem escapar da condição operária. os dados da pesquisa "Perfil da juventude brasileira", destaca que educação aparece como o assunto e o tema de maior interesse para os jovens (2005, pp. 109110). Souza (2003), em pesquisa realizada com jovens da última série do ensino médio noturno, mostra que esses alunos vêem a escola como um lugar de repetição e monotonia, que oferece um conhecimento inútil porque distante da realidade, cuja única importância é o fornecimento de um certificado. Ao contrário, o trabalho éo local onde existe ordem e disciplina, em que efetivamente se aprende e que fornece um sentido para a vida. $\mathrm{O}$ trabalho, e não a escola, representa "o novo, o inesperado" (p. 137).

20. Cabe aqui citar Bourdieu (1983, p. 115) quando diz que convém não esquecer que a escola "não é simplesmente um lugar onde se aprende coisas, saberes, técnicas etc.: é também uma instituição que concede títulos, isto é, direitos e, ao mesmo tempo, confere aspiraçōes".

novembro $2005 \quad 239$ 
No que se refere ao nível salarial (Tabela 14), o percentual de jovens que estava (na época) na faixa de $\mathrm{R} \$ 1.201,00$ a $\mathrm{R} \$ 1.800,00$ era, praticamente, o mesmo entre aqueles que se encontravam na faixa etária de 30 anos ou mais: $50 \%$ a 54\%. Em compensação, a proporção de jovens nas faixas salariais inferiores é quatro vezes maior do que os mais velhos, assim como é um pouco mais que o dobro a porcentagem dos trabalhadores acima de 30 anos que ganham salários superiores a $\mathrm{R} \$ 3.000,00$. Os jovens sobressaem apenas nas faixas intermediárias de salários: 36\% deles recebem salários que vão de $\mathrm{R} \$ 1.801 .00$ a $\mathrm{R} \$ 3.000,00$, contra $29 \%$ dos mais velhos.

TABELA 14

Nivel salarial

\begin{tabular}{|c|c|c|c|}
\hline & FAIXA ETÁRIA & 30 anos ou mais (\%) & Até 29 anos (\%) \\
\hline \multicolumn{4}{|l|}{ Nível SALARIAL } \\
\hline Até $\mathrm{R} \$ 600$ & & 1 & 0 \\
\hline De $\mathrm{R} \$ 601$ a $\mathrm{R} \$ 1.200$ & & 2 & 8 \\
\hline De $\mathrm{R} \$ 1.201$ a $\mathrm{R} \$ 1.800$ & & 54 & 50 \\
\hline De $\mathrm{R} \$ 1.801$ a $\mathrm{R} \$ 2.400$ & & 18 & 19 \\
\hline De $\mathrm{R} \$ 2.401$ a $\mathrm{R} \$ 3.000$ & & 11 & 17 \\
\hline Mais de $\mathrm{R} \$ 3.000$ & & 14 & 6 \\
\hline TOTAL & & 100 & 100 \\
\hline
\end{tabular}

O que esses dados estariam indicando? Como o grupo dos jovens tem maior qualificação, maior escolaridade formal, seria de se esperar que seus salários fossem mais altos. Entretanto, considerando os salários acima de $\mathrm{R} \$ 1.801,00$, vemos que as porcentagens de trabalhadores das duas faixas etárias praticamente se igualam: $43 \%$ dos mais velhos e $42 \%$ dos jovens aí se localizam. Para uma comparação mais refinada, contudo, seria preciso considerar o tempo de trabalho na empresa e, nesse caso, os jovens poderiam ter uma vantagem, visto que, mesmo com menos tempo na empresa, recebem salários praticamente equivalentes aos dos mais velhos.

É importante ressaltar que, da época em que foi realizada a pesquisa até setembro de 2005, ocorreram três aumentos e/ou reposições salariais. De acordo com os dados do Dieese, da subseção do sindicato dos metalúrgicos do $A B C$, para aqueles que ganhavam até $\mathrm{R} \$ 5.000,00$ no dia $1^{\circ}$ de setembro de 2005, o total da reposição salarial chegou a $41,36 \%$ nos últimos três anos.

Com relação à situação de moradia, na Tabela 15 , chama a atenção o fato de que aproximadamente $80 \%$ dos jovens entrevistados e $85 \%$ dos 
mais velhos habitam em moradia própria (já paga ou ainda pagando), o que diz muito do padrão de vida dos trabalhadores da indústria automobilística. Além disso, é possível supormos que uma parte dos mais novos, como são solteiros, morem com os pais.

TABELA 15

Situação da moradia

FAIXA ETÁria $\quad 30$ anos ou mais (\%) Até 29 anos (\%)

SitUAÇ̄̄o DA MORADIA

\begin{tabular}{lcc}
\hline Própria já paga & 63 & 64 \\
Própria ainda pagando & 22 & 15 \\
Alugada & 9 & 11 \\
Cedida de outra forma & 4 & 3 \\
Outra condição & 2 & 7 \\
\hline TOTAL & 100 & 100 \\
\hline
\end{tabular}

No que tange aos bens de consumo, como mostra a Tabela 16, os jovens trabalhadores das montadoras têm equipamentos domésticos que denotam um padrão de consumo de "classe média". Nos dois grupos de operários estudados, um número expressivo deles possui carro, máquina de lavar, computador etc. O que chama a atenção é que entre aqueles que estão na faixa etária de 19 a 29 anos, $93 \%$ possuem carro, contra $81 \%$ entre os mais velhos.

TABELA 16

Bens de consumo

\begin{tabular}{lcc}
\hline BeniXA ETÁria & 30 anos ou mais (\%) & Até 29 anos (\%) \\
\hline Geladeira & & 100 \\
Rádio & 99 & 100 \\
Televisão & 98 & 97 \\
Telefone fixo & 98 & 99 \\
Máquina de lavar roupa & 96 & 93 \\
Carro & 94 & 93 \\
Videocassete & 81 & 87 \\
Telefone celular & 82 & 77 \\
Forno de microondas & 52 & 75 \\
Computador & 71 & 66 \\
Internet & 48 & 55 \\
DVD & 35 & 32 \\
TV por assinatura & 15 & 22 \\
\hline
\end{tabular}


Outro aspecto que cabe ressaltar é o elevado percentual daqueles que possuem os itens de consumo considerados mais "modernos" na vida cotidiana, como internet, telefone celular, TV por assinatura, computador e DVD; mas, à exceção da TV por assinatura, o consumo desses bens é muito maior no grupo de menor faixa etária. Levando-se em conta que a pesquisa foi realizada entre março e junho de 2003, portanto há dois anos e meio, torna-se surpreendente o percentual de empregados que - à época - possuíam aparelhos de DVD e TV por assinatura.

\section{O trabalho na empresa}

Analisaremos em seguida um conjunto de tabelas sobre o trabalho que é executado na empresa, a avaliação que os trabalhadores fazem dele, bem como das relações de trabalho. Na Tabela 14, são fornecidas informações a respeito do tempo de trabalho na empresa, e alguns dados chamam a atenção: no grupo etário mais velho, cerca de 50\% têm mais de 16 anos de casa. Para os padrões brasileiros, esses dados são surpreendentes. Assim como também é surpreendente o fato de 14\% de empregados pertencentes a esse grupo estarem há mais de vinte anos trabalhando na montadora. De outra parte, no grupo dos jovens, quase $60 \%$ têm mais de seis anos de empresa e nada menos que $21 \%$ têm mais de onze anos.

TABELA 17

Tempo de trabalho na empresa

\begin{tabular}{|c|c|c|c|}
\hline TEMPO DE CASA & FAIXA ETÁRIA & 30 anos ou mais $(\%)$ & Até 29 anos (\%) \\
\hline Menos de 5 anos & & 2 & 20 \\
\hline 6 a 10 anos & & 18 & 58 \\
\hline 11 a 15 anos & & 29 & 21 \\
\hline 16 a 20 anos & & 37 & 1 \\
\hline Mais de 20 anos & & 14 & 0 \\
\hline TOTAL & & 100 & 100 \\
\hline
\end{tabular}

Também aqui os dados causam admiração, especialmente quando confrontados com pesquisas que revelam outra situação dos jovens no mercado de trabalho. Em sua maioria, os jovens empregados nas montadoras 
apresentam uma trajetória mais linear, tendo iniciado suas atividades na empresa após o curso técnico feito no Senai. Como dissemos anteriormente, quase metade deles está no seu primeiro emprego, enquanto $28 \%$ já tinham experiência de trabalho na indústria, dos quais 16\% no setor metalúrgico. Os jovens encontrados por Souza Martins (2004) nas metalúrgicas de Osasco apresentam, diferentemente, uma trajetória marcada por flutuações e descontinuidades, combinando momentos de atividade e de desemprego, e o trânsito entre os setores da indústria, do comércio, de serviços e da construção civil. Os dados dessa pesquisa mostram que $72,2 \%$ dos jovens tinham até dois anos de trabalho na empresa e apenas $27,8 \%$ estavam empregados há mais de três anos. A experiência em empregos temporários, sem carteira assinada, por curtos períodos, permanecendo geralmente entre três meses e um ano, marca as trajetórias desses jovens. Esse quadro, aliado à alta taxa de desemprego juvenil, tem levado à interpretação (cf. Madeira, apud Corrochano, 2005, p. 208) de que a rotatividade no emprego expressa uma maior "propensão" do jovem de transitar para o desemprego e a inatividade. Esse movimento de entrada e saída do mercado de trabalho, combinando às vezes educação e emprego - o que Pais (2001) chama muito apropriadamente de "trajetórias ioiô" -, seria para esses autores apenas uma questão de propensão dos indivíduos, que "escolhem" trabalhar ou não!

As Tabelas 18, 19 e 20 trazem dados interessantes com relação aos dois grupos estudados. Em geral, nos aspectos relacionados ao cotidiano do trabalho na fábrica, os jovens trabalhadores têm idéias bem mais críticas sobre esses temas do que os trabalhadores que estão na faixa etária mais alta. No que se refere às relações de trabalho (Tabela 18), os jovens concentram suas opiniōes entre as faixas boa e razoável (86\%), enquanto os trabalhadores com mais de 30 anos as consideram boas e ótimas (71\%).

TABELA 18

Opiniāo sobre relação empresalfuncionário

\begin{tabular}{lcc}
\hline FAIXA ETÁrIA & 30 anos ou mais (\%) & Até 29 anos (\%) \\
\hline Ótima & 21 & 7 \\
Boa & 60 & 54 \\
Razoável & 18 & 32 \\
Ruim & 1 & 7 \\
\hline Total & 100 & 100 \\
\hline
\end{tabular}


Quanto às condições de trabalho (Tabela 19), os mais velhos as vêem como boas e ótimas (83\%), enquanto os jovens as avaliam como razoáveis e boas $(86 \%)$.

TABELA 19

Opiniāo sobre as condiçôes de trabalho

\begin{tabular}{|c|c|c|c|}
\hline CONDIÇóES DE TRABALHO & FAIXA ETÁRIA & 30 anos ou mais $(\%)$ & Até 29 anos (\%) \\
\hline Ótimas & & 19 & 10 \\
\hline Boas & & 64 & 61 \\
\hline Razoáveis & & 16 & 25 \\
\hline Ruins & & 1 & 4 \\
\hline TOTAL & & 100 & 100 \\
\hline
\end{tabular}

Pela Tabela 20, apesar dessa perspectiva mais crítica dos jovens, vemos que $85 \%$ deles sentem orgulho de trabalhar na empresa, enquanto $96 \%$ dos entrevistados com 30 anos ou mais responderam afirmativamente a essa questão. Por fim, 3\% dos mais velhos não souberam responder, contra $11 \%$ daqueles que se situam na faixa etária de 19 a 29 anos.

TABELA 20

Valorização do trabalho na empresa

\begin{tabular}{|c|c|c|c|}
\hline & FAIXA ETÁRIA & 30 anos ou mais $(\%)$ & Até 29 anos (\%) \\
\hline \multicolumn{4}{|c|}{ VALORIZAÇĀO DO TRABALHO NA EMPRESA } \\
\hline Sim & & 96 & 85 \\
\hline Não & & 1 & 4 \\
\hline Não sei & & 3 & 11 \\
\hline TOTAL & & 100 & 100 \\
\hline
\end{tabular}

O percentual referente às respostas "Não sei" também pode expressar certa indiferença com relação à empresa e, no limite, pode reafirmar a postura mais crítica com relação à companhia. Apesar disso, o que esses dados parecem indicar é que ainda existe por parte dos jovens uma valorização do trabalho nas montadoras. Quando indagados sobre o que significa trabalhar em uma dessas empresas, evidenciam tanto a preocupação com o futuro da família como a valorização dos salários maiores, com $74 \%$ e $76 \%$, respectivamente, das indicações. Mas $40 \%$ buscam também o respeito como trabalhador que o emprego na montadora lhes oferece. Para os

244 Tempo Social, revista de sociologia da USP, v. 17, n. 2 
jovens trabalhadores da Mercedes-Benz, contudo, há uma atração maior do que essa: $44 \%$ indicam o estímulo aos estudos, expresso por meio da ajuda de custo aos estudantes fornecida pela empresa.

A pesquisa de Tomizaki (2005) com os jovens trabalhadores da Mercedes-Benz permite avançar um pouco mais na compreensão das diferenças de avaliação entre os dois grupos etários. Os trabalhadores mais velhos entrevistados por ela comparam dois momentos em que as condições de trabalho e as relaçôes com a empresa se apresentam de maneira diversa. Antes "era uma escravidão" e hoje houve uma melhoria, com mais liberdade, "um ambiente tranqüilo, um excelente ambiente de trabalho" (Idem, p. 65). As relações de trabalho, especialmente com a chefia, eram difíceis, não suportando questionamentos ou reivindicaçóes por parte dos empregados, o que levou um dos entrevistados a afirmar que "antigamente, era na base do chicote que a gente trabalhava" (Idem, p. 55). Por isso, talvez, os trabalhadores que viveram esse "tempo de antes" avaliem mais positivamente as relações de trabalho, por possuírem elementos para a comparação, enquanto os jovens, inseridos no processo de produção no tempo marcado pelas novas formas de gerir e organizar o trabalho, são capazes de elaborar também novas exigências. Os mais velhos explicam, com muita clareza, que as mudanças para melhor nas condiçôes de exercício do trabalho decorreram da reestruturação produtiva e da criação da Comissão de Fábrica. A Mercedes-Benz foi a última montadora a permitir a organização de trabalhadores no local de trabalho, mas, a partir disso, as relações de poder no interior da empresa foram alteradas.

Nessa análise sobre a valorização do trabalho nas montadoras, cabe ainda uma palavra a respeito do sonho de trabalhar na indústria metalúrgica e, especialmente, nas montadoras do $\mathrm{ABC}$, que os trabalhadores de diversas gerações têm manifestado. Não se trata apenas de buscar trabalho que garanta bons salários e perspectiva de firmar-se em uma profissão, mas há também um alto valor simbólico, que confere status, reconhecimento, afirmação pessoal e social. Nas pesquisas que tomamos como referência neste artigo, observa-se o constante empenho dos jovens e de suas famílias de conseguirem apoio de amigos, vizinhos e parentes que já trabalham nessas empresas. Em nossa pesquisa, 36\% dos jovens têm pais que trabalham em montadoras, sendo que a maior porcentagem está na Volkswagen (58\%). No texto de Tomizaki, um jovem entrevistado relatou a emoção de seu pai, também trabalhador da Mercedes-Benz, quando viu um de seus filhos trabalhando de macacão na linha de montagem. 
21. A pesquisa realizada por Corrochano (2001) mostra uma taxa de sindicalização de $57 \%$. O que se observa no caso dos jovens dessa pesquisa é que a sindicalização é maior entre os jovens com mais idade (22 a 24 anos), os que têm mais tempo na empresa, entre os trabalhadores semiqualificados e qualificados, e os que trabalham nas maiores empresas.
A posição mais crítica dos jovens não impede, portanto, o reconhecimento das vantagens de trabalhar em uma indústria como as montadoras de automóveis. Mas expressa a insatisfação, a busca de um futuro diferente do de seus pais, fora da fábrica, em que se possa aproveitar o investimento feito no curso superior. Eles sabem que são diferentes de seus pais, foram mais além do que eles em termos educacionais e profissionais, e, portanto, merecem mais do que eles. Bourdieu fornece-nos o registro para entender essa "revolta confusa" que não consegue se expressar de forma organizada e que

[...] não é aquilo que se entende comumente por politização, isto é, aquilo que os aparelhos políticos estão preparados para registrar e fortalecer. É um questionamento mais geral, mais vago, uma espécie de mal-estar no trabalho, algo que não é político no sentido estabelecido, mas que poderia sê-lo; algo que se parece muito a certas formas de consciência política ao mesmo tempo cegas em relação a si mesmas, porque não acharam seu discurso, e com uma força revolucionária extraordinária capaz de superar os aparelhos [...] (1983, p. 118).

Esses argumentos permitem-nos entender os dados referentes à politização desses jovens trabalhadores, por meio das taxas de sindicalização e de participação nas atividades sindicais. Como dissemos anteriormente, a taxa de sindicalização nas montadoras é de $76 \%$ e, como a pesquisa foi feita só com sindicalizados, estamos diante de trabalhadores que apresentam um vínculo expressivo com sua entidade sindical ${ }^{21}$. Entretanto, quando consultados a respeito do engajamento na vida sindical, 79\% dos jovens afirmam que participam pouco ou não participam. A opinião sobre a atuação do sindicato também expressa certa postura crítica, já que $81 \%$ a consideram boa ou regular. Mas, no geral, com relação ao empenho do sindicato nas questôes que afetam a vida dos trabalhadores, esses jovens avaliam-no positivamente. Da mesma forma, se a atuação da comissão de fábrica é vista como ótima por apenas $8 \%$ deles, $87 \%$ a consideram entre boa e regular. Pode-se concluir que, por parte dos jovens, existe o reconhecimento da importância do sindicato para a construção da identidade operária, mas não há uma identificação tão estreita como a que marcou a geração que se envolveu nas lutas do final dos anos de 1970 e parte dos anos de 1980. A expressão dessa herança pode ser percebida quando $75 \%$ dos jovens declaram a sua preferência pelo Partido dos Trabalhadores e apenas 19\% afirmam não ter nenhum interesse partidário. Os jovens das montadoras apóiam as lutas sindicais, 
têm consciência de seus significados, até escolhem seu partido político, mas não têm interesse pela política, afastam-se da militância, seja a sindical, seja a partidária. É como se existisse uma cultura da desconfiança, certo mal-estar e distanciamento.

Contudo, a pesquisa de Tomizaki dá uma informação importante: a idade média de entrada no movimento sindical das lideranças da primeira geração é de 30 anos, enquanto para os jovens representantes a média caiu para 23 anos. Esse dado ajuda-nos a relativizar a discussão a respeito da participação política dos jovens, acatando estudos que procuram mostrar as formas pelas quais os jovens se expressam politicamente hoje (cf. Ponte de Sousa, 1999; Novaes, 2000), sem estabelecer comparações com as gerações anteriores. Afinal, como lembra um trabalhador da geração mais velha entrevistado por Tomizaki, “'em sua época', os jovens também participavam pouco e precisavam ser 'puxados' pelos mais velhos” (2005, p. 230).

A análise desenvolvida até aqui mostrou que, em certos aspectos, a situação dos jovens trabalhadores em montadoras é melhor do que a de outros jovens inseridos no mercado de trabalho e, em todos os sentidos, superior à dos jovens que permanecem à margem do trabalho, seja como desempregados, seja como subempregados. Essas diferentes juventudes vivenciam condiçôes de vida e de trabalho caracterizadas pela diversidade quanto a escolaridade, qualificação profissional, tempo de trabalho na empresa, tipo de contrato de trabalho, estabilidade no emprego, salários, acesso a bens de consumo e possibilidades de estabelecer projetos para o futuro. Diante das incertezas do mundo globalizado que afetam a todos, os jovens trabalhadores das montadoras parecem protegidos, pois estão empregados e, melhor ainda, em empresas que constituem o sonho de grande parte da juventude. Entretanto, o que nosso estudo demonstra é que eles também são atingidos pela insatisfação e pelo medo. Insatisfação quanto às condições de trabalho, quanto ao reconhecimento de seus esforços e da competência adquirida na escola. Afinal, apesar do curso técnico, $59 \%$ deles são classificados pelas empresas como trabalhadores semiqualificados. $\mathrm{O}$ trabalho que executam não exige muitos conhecimentos e o que aprenderam em escolas como o Senai não é usado e corre o risco de ser esquecido (cf. Tomizaki, 2005, p. 159). Além disso, os trabalhadores hoje vivem marcados por uma cultura do medo (cf. Novaes, 2000) ${ }^{22}$, diante da possibilidade da perda do emprego, de não encontrar um trabalho, de não ter as qualidades ou as habilidades para executar o serviço, ou seja, diante da possibilidade de fracassarem. É essa cultura que faz com que jovens que
22. Tomamos emprestada da autora a expressão, ainda que ela se refira particularmente aos jovens nascidos nos anos de 1970 no Rio de Janeiro, diante da violência. 
ainda não chegaram aos 24 anos afirmem que estão "velhos" para ingressar no mercado de trabalho (cf. Corrochano, 2005)!

Por isso, não é estranho o fato de que, em nossa pesquisa, 76\% dos jovens metalúrgicos declarem sua preocupação em perder o emprego. $\mathrm{Ou}$ que, na pesquisa "Perfil da juventude brasileira", o desemprego apareça como o principal problema do Brasil na atualidade (cf. Guimarães, 2005, pp. 160-161). Os jovens têm consciência da situação que vivem e, mesmo aqueles que aparentemente não foram atingidos pelas mazelas que afligem a juventude hoje, manifestam sua inquietação diante do futuro.

\section{Referências Bibliográficas}

Almeida, Maria Hermínia Tavares de. (1975), “O sindicato no Brasil: novos problemas, velhas estruturas". Debate \& Crítica, 6, jul., São Paulo.

Antunes, Ricardo. (1988), A rebeldia do trabalho. São Paulo, Editora da Unicamp/ Ensaio.

(1991), O novo sindicalismo. São Paulo, Brasil Urgente.

Blass, Leila. (2001), De volta ao futuro. São Paulo, Edusc/Fapesp/Cortez.

Boito Júnior, Armando (org.). (1991), O sindicalismo brasileiro nos anos 80. São Paulo, Paz e Terra.

Bourdieu, Pierre. (1983), “A juventude é apenas uma palavra”. In: Questôes de sociologia. Rio de Janeiro, Marco Zero, pp. 112-121.

Candido, Antonio. (1964), Os parceiros do Rio Bonito. Rio de Janeiro, José Olympio. Comin, Álvaro Augusto, Cardoso, Adalberto Moreira \& Campos, André Gambier. (1997), "As bases sociais do sindicalismo metalúrgico". In: ArBIX, Glauco \& Zilbovicius, Mauro (orgs.). De JK a FHC: a reinvenção dos carros. São Paulo, Scritta.

CONCEIÇão, Jefferson da. (2001), As fábricas do ABC no olho do furacão: a indústria de autopeças e a reestruturação da cadeia de produção automotiva nos anos 90. Dissertação de mestrado, São Caetano do Sul, IMES - Centro Universitário Municipal de São Caetano do Sul.

Corrochano, Maria Carla. (2001), Jovens olhares sobre o trabalho: um estudo dos jovens operários e operárias de São Bernardo do Campo. Dissertação de mestrado, Faculdade de Educação da Universidade de São Paulo.

. (2005), Políticas públicas e trajetórias juvenis no mundo do trabalho: um estudo dos jovens egressos do Programa Bolsa Trabalho do município de São Paulo. Primeiro Relatório Científico, Fapesp.

Galvão, Andréia. (1996), Participação e fragmentação: a prática sindical dos metalúr- 
gicos do $A B C$ nos anos 90. Dissertação de mestrado, Campinas, Departamento de Ciência Política da Universidade de Campinas.

GRANDE ABC EM NÚMEROS. São Bernardo, Subseção Dieese-SMABC, mar. 2003.

Guimarāes, Nadya Araujo. (2005), "Trabalho: uma categoria-chave no imaginário juvenil?”. In: Abramo, Helena W. \& Branco, Pedro Paulo M. (orgs.). Retratos da juventude brasileira: análises de uma pesquisa nacional. São Paulo, Instituto Cidadania/Fundação Perseu Abramo, pp. 149-174.

KLINK, Jeroen Johannes. (2001), A cidade-regiāo: regionalismo e reestruturaçāo no grande $A B C$ paulista. Rio de Janeiro, DP\&A.

Mangabeira, Wilma. (1993), Os dilemas do novo sindicalismo. Rio de Janeiro, Relume Dumará/Anpocs.

Mannheim, Karl. (1982), "O problema sociológico das gerações". In: Foracchi, Marialice M. (org.). Mannheim. São Paulo, Ática (col. Grandes Cientistas Sociais, 25), pp. 67-95.

Maroni, Amnéris. (1982), A estratégia da recusa. São Paulo, Brasiliense.

Martins Rodrigues, Leôncio. (1970), Industrialização e atitudes operárias. São Paulo, Brasiliense.

. (1990a), "Trabalhadores de uma indústria automobilística: perfil social e participação sindical". In: Partidos e sindicatos. São Paulo, Ática.

(1990b), CUT: os militantes e a ideologia. São Paulo, Paz e Terra.

Novaes, Regina R. (2000), "Juventude e participação social: apontamentos sobre a reinvenção da política”. In: ABRAmO, Helena W. et al. (orgs.). Juventude em debate. São Paulo, Cortez/Ação Educativa, pp. 46-69.

. (2005), "Juventude, percepçôes e comportamentos: a religião faz diferença?". In: Abramo, Helena \& Branco, Pedro Paulo (orgs.). Retratos da juventude brasileira: análises de uma pesquisa nacional. São Paulo, Instituto Cidadania/Fundação Perseu Abramo, pp. 263-290.

Oliveira, Marco Antonio. (2002), Politica trabalhista e relaçōes de trabalho no Brasil: da era Vargas ao governo FHC. Tese de doutorado, Campinas, Instituto de Economia, Universidade de Campinas.

PAIs, José Machado. (2001), Ganchos, tachos e biscates: jovens, trabalho e futuro. Porto, Ambar.

Paranhos, Kátia Rodrigues. (1999), Era uma vez em São Bernardo. Campinas, Editora da Unicamp.

. (2002), Mentes que brilham: sindicalismo e práticas culturais dos metalúrgicos de São Bernardo. Tese de doutorado, Campinas, Departamento de História da Universidade de Campinas.

PonTe De SousA, Janice Tirelli. (1999), Reinvençôes da utopia: a militância política de jovens nos anos 90. São Paulo, Hacker Editores/Fapesp. 
Rainho, Luís Flávio \& Bargas, Osvaldo Martines. (1983), As lutas operárias e sindicais dos metalúrgicos em São Bernardo (1977-1979). São Bernardo, Associação Beneficiente e Cultural dos Metalúrgicos de São Bernardo do Campo e Diadema. RODRIGUeS, Iram Jácome. (1990), Comissão de fábrica e trabalhadores na indústria. São Paulo, Cortez/Fase.

. (1997), Sindicalismo e política: a trajetória da CUT. São Paulo, Scritta/Fapesp. . (2002), "Um laboratório das relaçôes de trabalho: o ABC paulista nos anos 90". Tempo Social, 14 (1), maio.

. (2005a), "Peculiaridades da ação sindical dos metalúrgicos do ABC". Revista de Direito do Trabalho. Editora Revista dos Tribunais, 119, jul./set., São Paulo. Rodrigues, Karine. (2005b), "Para ONU, jovens estão em risco". O Estado de S. Paulo, 5 out., p. A20.

SADER, Eder. (1988), Quando novos personagens entraram em cena. São Paulo, Paz e Terra. Santana, Marco Aurélio. (1999), "Política e história em disputa: o 'novo sindicalismo’ e a idéia de ruptura com o passado". In: RodRigues, Iram Jácome (org.). $O$ Novo Sindicalismo, vinte anos depois. Petrópolis, Vozes/Educ/Unitrabalho.

SOARES, José de Lima. (1998), Sindicalismo no ABC paulista: reestruturação produtiva e parceria. São Paulo, Outubro.

SouZA, Regina Magalhães de. (2003), Escola e juventude: o aprender a aprender. São Paulo, Educ/Paulus.

Souza Martins, Heloisa Helena T. de. (1994), Igreja e movimento operário no ABC. São Paulo, Hucitec.

(1997), "O jovem no mercado de trabalho". In: Peralva, Angelina T. \& Sposito, Marilia P. (orgs.). Juventude e contemporaneidade. Revista Brasileira de Educação, Anped, n. 5 (maio/jun./jul./ago.) e n. 6 (set./out./nov./dez.), pp. 96109.

(2001), "O processo de reestruturação produtiva e o jovem trabalhador: conhecimento e participação". Tempo Social, 13 (2): 61-87, nov.

(2004), "A difícil transição: análise das trajetórias ocupacionais de jovens operários metalúrgicos”. In: Dowbor, Ladislau et al. (orgs.). Desafios do trabalho. Petrópolis, Vozes, pp. 169-186.

Sposito, Marilia Pontes. (2005), "Algumas reflexões e muitas indagações sobre as relações entre juventude e escola no Brasil”. ABramo, Helena W. \& Branco, Pedro Paulo M. (orgs.). Retratos da juventude brasileira: análises de uma pesquisa nacional. São Paulo, Instituto Cidadania/Fundação Perseu Abramo, pp. 87-127.

TOMIZAKI, Kimi. (2005), Ser metalúrgico no ABC: rupturas e continuidades nas relações intergeracionais da classe trabalhadora. Tese de doutorado, Campinas, Faculdade de Educação da Universidade de Campinas.

250 Tempo Social, revista de sociologia da USP, v. 17, n. 2 
Véras de Oliveira, Roberto. (2002), Sindicalismo e democracia no Brasil: atualizaçôes (do novo sindicalismo ao sindicato cidadão). São Paulo, Departamento de Sociologia da USP.

Waterman, Peter. (1999), "A new union model for a new world order". In: MuncK, Ronaldo \& Waterman, Peter. Labour worldwide in the era of globalization. London, Macmillan Press.

\section{Resumo}

Perfil socioeconômico de jovens metalúrgicos

Este artigo analisa os dados de pesquisa realizada com trabalhadores da indústria automobilística na regiáo do $\mathrm{ABC}$, com destaque para aqueles em faixa etária entre 19 e 29 anos, efetuando uma comparação entre o perfil socioeconômico desses jovens metalúrgicos e o de seus colegas de trabalho com 30 anos de idade ou mais. Destacando a heterogeneidade que caracteriza a juventude, os autores mostram as diferenças existentes não só entre os trabalhadores mais jovens e os mais velhos, mas também entre os jovens metalúrgicos e aqueles investigados em pesquisas anteriores. A análise mostrou que, se em determinados aspectos a situação dos jovens trabalhadores em montadoras é melhor do que a de outros jovens inseridos no mercado de trabalho e, em todos os sentidos, superior à dos jovens que permanecem à margem do trabalho, seja como desempregados, seja como subempregados, isso não significa, contudo, que não apresentem insatisfaçōes e temores diante das incertezas do mundo globalizado.

Palavras-chave: Jovem trabalhador; Indústria automobilística; Sindicalismo; Região do ABC.

\section{Abstract}

\section{Socio-economic profile of young metalworkers}

This paper analyses data from a research done with automobile workers in the $\mathrm{ABC}$ region (in the State of São Paulo), with special emphasis on those who are between 19 and 29 years of age. A comparison of their socio-economic profile was made with that of their colleagues who are thirty or over. Pointing out the heterogeneity that characterizes youth, the text shows the existing differences, not only between the younger and the older metal workers, but also between the young metal workers and other youths that took part in previous researches. The analysis shows that, to a certain extent, those working in the automobile industry are better off than that other youths in the labor market in general, and in all senses, their situation is a lot superior to that of youths who have not been absorbed by the market, either because they are unemployed, or because they are underemployed. This does not mean, however, that these 
young metal workers are satisfied or that they are not fearsome of the uncertainties of a globalized world.

Keywords: Young workers; Automobile industry; Trade unionism; ABC region.

Texto recebido e aprovado em 20/10/2005.

Iram Jácome Rodrigues é professor do Departamento de Economia e do Programa de PósGraduação em Sociologia da USP e pesquisador do CNPq. E-mail: ijrodrig@usp.br

Heloisa Helena T. de Souza Martins é professora do Programa de Pós-Graduação em Sociologia da USP. E-mail: heloisah@usp.br 